\title{
New hope for unsanctioned safe injection site
}

\author{
Cite as: CMAJ 2018 January 22;190:E90-1. doi: 10.1503/cmaj.109-5547
}

Posted on cmajnews.com on Jan. 4, 2018.

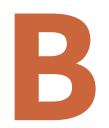

ehind an accordion divider in a heated trailer in Moss Park, Toronto, harm reduction volunteer Zoë Dodd administers the anti-overdose drug naloxone to an unconscious young woman. On the other side of the divider, six people wait to inject drugs.

"What did she take? Was it beige?" a woman called 'Legs' asks Dodd. Legs opens a tiny paper packet of fentanyl; she's worried about its colour.

"Just take a little bit, don't take a lot," Dodd offers.

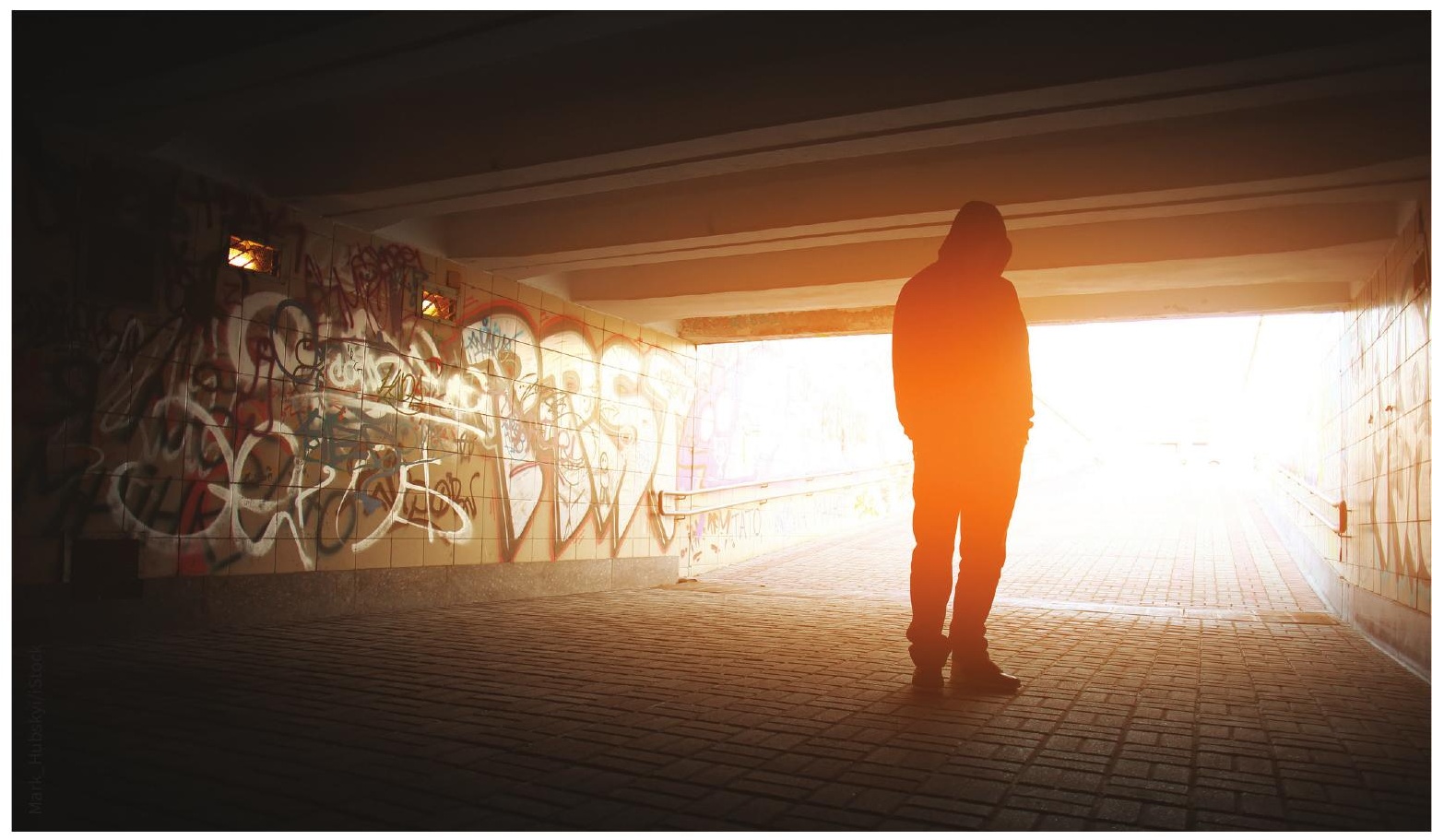

A federal announcement may mean a less uncertain future for a successful yet unorthodox safe injection site.

Legs nods. "I don't want to go down," she says. Before she started coming here to inject every night, Legs overdosed five times in a week and was treated with naloxone by friends. "Here is a lot safer for me."

The Toronto Overdose Protection Site, or TOPS, was the first safe injection site in the city when it opened in August last year. Run by volunteers without federal or provincial approval, the pop-up site still operates in a legal vacuum. "It's definitely a grey zone, although we have tacit approval from both the city and the police," says Leigh Chapman, a nurse who volunteers at the site.

Now, a path to official sanction may be opening. In December, the federal government announced it would allow Ontario to approve and fund safe injection sites without requiring the sites to apply individually to Health Canada for exemption from federal drug laws.

"This onerous process of getting exemptions is resulting in people dying," says Joe Cressy, a Toronto city councillor who chairs the city's drug strategy implementation panel. In 2013, a needs assessment concluded that Toronto needed three to five supervised injection sites. Two sanctioned sites opened in 2017 and at least two more will open in early 2018. But Cressy says "the overdose crisis that exists today is far worse," and pop-up sites like TOPS can play an important role in filling gaps. Not all city officials agree; in November, Mayor John Tory suggested the opening of a sanctioned site on the other side of Moss Park should render the pop-up unnecessary.
Ontario is still working on a model and approval process for overdose prevention sites. In the meantime, TOPS can now apply for provincial funding, but Chapman says she's not sure they will. Getting funded by the government would mean operating by their rules, and there are many things the pop-up site does differently.

Notably, TOPS has a tent for smoking and volunteers do not stop people from helping others to inject drugs. Assisted injection is not allowed at governmentfunded sites, including InSite in Vancouver, because it's against the law. Advocates say this forces those who cannot inject themselves to use drugs in unsafe conditions.

Another difference is that injections are monitored by both a nurse and a 
harm reduction volunteer who has experience using drugs. "People feel way more comfortable with someone who knows what they're going through, than with someone who's gone to school and learned what they're going through," says Leon 'Pops' Alward, a volunteer who injected drugs for 15 years. Harm reduction volunteers also have medically important knowledge about the drugs people use and the language they use to describe them.

This unorthodox approach appears to work. Statistics suggest that more people use the TOPS site than a sanctioned site operated by Toronto Public Health at the
"Works," six blocks away. As of Dec. 2, the Works staff had responded to 22 overdoses, according to Dr. Eileen de Villa, Toronto's medical officer for health. Meanwhile, TOPS had treated 120 overdoses by late December. Both sites launched in August and are open from $4 \mathrm{pm}$ to $10 \mathrm{pm}$.

A man standing outside the Works explains that while he occasionally uses the sanctioned site, he prefers the Moss Park pop-up. "It's more comfortable, it's more your own spot." The public health site is "too sterile," he says.

However, another client of the Works says he prefers the site. "It's good that it's sterile, it's safer." The Works also provides referrals to housing supports, income assistance and addiction treatment official links TOPS can't make.

According to Chapman, the city recently began providing transit tokens for clients to get from TOPS to shelters or warming centres. She says the site will continue to operate, with or without public funding, and has raised over $\$ 80000$ through crowdfunding. "We have built strong connections with people who have been completely neglected by the society at large. How do you abandon those connections?"

Wendy Glauser, Toronto, Ont. 